\title{
Effect of Working Capital Management of the Profitability of Listed Pharmaceutical Firms in Nigeria
}

\author{
Ado Ahmed*, Lawal Qodiri Olayinka, Angulu Ramatu Abdullahi, Mahfuza Adamu Yayaji \\ Department of Accounting, Faculty of Management Technology, Abubakar Tafawa Balewa University, Bauchi
}

DOI: $10.36348 / \mathrm{sb} .2019 . v 05 i 12.014$

| Received: 20.11.2019 | Accepted: 27.11.2019 | Published: 26.12.2019

*Corresponding author: Ado Ahmed

\section{Abstract}

The study examined the impact of working capital management on the profitability of Pharmaceutical firms listed on the Nigerian Stock Exchange market. Correlation and ex-post facto research design were used in a sample of 5 Pharmaceutical firms. Secondary data for a period of 5 years (2013-2018) was used, and Ordinary Least Squares (OLS) multiple regression was employed in data analysis. The study found that working capital management (account receivables collection management, accounts payables management, inventory management, cash conversion cycle management, operating cash flow management) has a significant impact on the profitability of listed pharmaceutical firms in Nigeria. It is therefore recommended among others that managers should focus on reducing inventory days, collect receivable as soon as possible because it is better to received inflows sooner than later, and delay payment of creditors in order to invest the money in short-term securities which are profitable. Also, the cash conversion cycle should be elongated to the extent that it maximizes profit.

Keywords: Working Capital, Working Capital Management, Profitability, listed pharmaceutical firms in Nigeria.

Copyright @ 2019: This is an open-access article distributed under the terms of the Creative Commons Attribution license which permits unrestricted use, distribution, and reproduction in any medium for non-commercial use (NonCommercial, or CC-BY-NC) provided the original author and source are credited.

\section{INTRODUCTION}

Working Capital is the flow of ready funds necessary for the working of a concern. It comprises funds invested in current assets, which in the ordinary course of business can be turned into cash within a short period without undergoing diminishing in value and without disruption of the organization [1]. Working capital is a vital element in any organizational setting that requires cogent attention, proper planning and management [2]. A positive working capital indicates the ability of the business to pay off its short term obligations at most when request comes from suppliers but a negative working capital indicates the inability of the business organization to pay short term obligations. As such, excessive working capital indicates an accumulation of idle current assets, which do not contribute in generating income for the firm during the operating period. Inadequate working capital on the other hand harms the credit worthiness and the day-today activities of firms, which may lead to insolvency [3].

This study focuses on pharmaceutical companies in Nigeria; the pharmaceutical industry manufactures and distributes drugs and medical equipment to the Nigerian populace.

Nigeria as an African nation with over 200 million citizens is known with high demand of drugs and adequate health care services to address medical problems. Despite the high demand of pharmaceutical business in Nigeria, the market is described as one of the smallest among Middle and East African (MEA) region [4]. With the exception of a few globally recognized brands, many of the pharmaceutical companies and health care providers in Nigeria cannot adequately compete internationally [4]. However, several effects particularly from foreign agencies and governments are in place to improve the pharmaceutical industry in Nigeria.

However, it is necessary and logical to carry out a study on the performance in relation to the management of working capital of the Nigerian pharmaceutical companies. The rationale is to provide empirical evidences as to the effectiveness of the financial management of the pharmaceutical firms, in line with the effort of improving the sector. It is against 
this background that this study attempt to assess the impact of working capital management and the profitability of listed pharmaceutical firms in Nigeria.

\section{Statement of the Problem}

One of the major objectives of working capital management is to ensure that corporate entities have sufficient, regular and consistent cash flow to fund their activities. Therefore, efficient working capital management could enable firms in sustaining growth which, in turn leads to strong liquidity and profitability for ensuring effective and efficient customer services. As such efficient management of working capital is very vital for a business survival.

According to Lead capital limited [4] drug manufactures in Nigeria are faced with several constraints, including low capacity utilization, under capitalization, a weak financial base, high production costs as a result of the high cost of inputs and unstable demand among others. While efforts have been made by previous researchers to proper solutions to these issues, little has been made to investigate the short-term liquidity problems with respect to working capital management. Moreover, the extent to which working capital management affects profitability of these firms is not adequately researched, this constitute the problem of this study. And, this also led to the research question on how does the management of working capital components impacted the profitability of listed pharmaceutical firms in Nigeria? However, working capital management has been empirically examine in many different ways, while some authors studied the impact of an optimal inventory management; others have studied the optimal way of managing accounts receivables that leads to profit maximization [5]. Other studies have Dong \& Su [6]; Sharma \& Kumar [7]. Most of these studies concentrated on a single working capital component and the study are mostly from the developed economy, where the market mechanisms and the business environment significantly differ from Nigeria. This provided a gap for this study to fill.

\section{OBJECTIVES OF THE STUDY}

The purpose of this study is to examine the impact of working capital management on the profitability of listed pharmaceutical firms in Nigeria.

\section{Hypotheses of the study}

This study follows the trend of existing literature and use profitability as a proxy of pharmaceutical firm's working capital and accordingly hypotheses are formulated

H01: Receivables collection management has no significant impact on the profitability of the listed pharmaceutical firms in Nigeria.
H02: Accounts payable management has no significant impact on the profitability of listed pharmaceutical firms in Nigeria.

H03: Inventory management has no significant impact on the profitability of listed pharmaceutical firms in Nigeria.

\section{Conceptual Issues}

In this section, conceptual issues relating to working capital, working capital management, objectives of working capital management, working capital management policies, working capital management in developing economies and profitability are discussed and presented.

\section{Working Capital Components}

According to Van Horne and Wachowicz [8] the necessary components of an organization's working capital, basically, depend on the type of business and industry. They further narrate that Cash, debtors, receivables, inventories, marketable securities, and redeemable futures can be recognized as the common components of organization's working capital. However, the question is to recognize the factors that determine the adequacy of working capital based on growth, size, operating cash flow, etc. The inability to understand the determining factors and measurement of adequate amounts of working capital will lead an organization to bankruptcy.

\section{Concept of Working Capital Management}

Van Horne [9] defined working capital management as the administration of current assets in the name of cash, marketable securities, receivables and staff advances, and inventories. Osisioma [10] demonstrated that good working capital management must ensure an acceptable relationship between the different components of a firm's working capital so as to make an efficient mix, which will guarantee capital adequacy. Therefore, working capital management should make sure that the desirable quantities of each component of the working capital are available for management

\section{Objectives of Working Capital Management}

One of the modern systems of corporate governance is management by objective that is all the organizational activities should be focused on the firm objectives. However, to be effective, working capital management requires a clear specification of the objectives to be achieved. The two main objectives of working capital management are to increase the profitability of a company and to ensure that it has sufficient liquidity to meet short-term obligations as they fall due and so continue in business [11]. Profitability is related to the goal of shareholder wealth 
maximisation, so investment in current assets should be made only if an acceptable return is obtained.

Accounts Receivables Management: This constitutes that management of firms' debtors. Accounts receivables period is the average time taken by credit customers to settle their accounts. Van Horne [9] states that, since the purpose of offering credit are to maximise profitability, the costs of debt collection should not be allowed to exceed the amounts recovered. More so, a company should prepare regularly aged trade receivables analysis and take steps to chase late payers. It is helpful to establish clear procedures for chasing late payers, to set out the circumstances under which credit control staff should send out reminders and initiate legal proceedings. Some thought could also be given to charging interest on overdue accounts to encourage timely payment, depending on the likely response of customers Van Horne and Wachowicz [8].

Accounts Payables Management: The accounts or trade payables deferral period is the average time taken by a company to pay its trade payables, i.e. its suppliers [12]. Current liabilities include all obligations, which mature within a year such as creditors, bills payable, accrued expenses, short-term bank loan, income tax liability and long-term debt excluding bank overdraft, all of which quickly mature in the current year.

Uyar [12] opined that, accounts payables or Creditors Turnover ratio is used to know how much credit time received by the firm from its trade creditors. Creditors' turnover ratio shows the breathing time received by the firm in terms of payment of credit purchase. Hence, the effectiveness lies in whether the firm is enjoying the actual credit period promised by 28 suppliers. It is calculated by dividing the amount of purchases by creditors. Here it has been assumed that all of the purchases have been made as credit purchases. The account payables period is computed by dividing account payables by net purchases multiplied by 365 days [13].

Inventory Management: Inventory turnover in days is another important component of working capital management which is also called as inventory conversion period [13]. According to them it is the average time required to convert materials into finished goods and then to sell those goods. This variable helps in evaluating the efficiency in inventory management policy of the firm. If the firms take more time in selling inventory which means inventories are not getting convert into sales, will decrease the profitability of firm. Inventory Turnover in Days is calculated using inventory divided by the cost of sales multiplied by 365 days.
Cash Management: According to Van Horne [9] there are three reasons why companies choose to hold cash. These are Transactions motive, precaution motive, and speculation motive. Transaction Motive, companies need a cash reserve in order to balance short-term cash inflows and outflows since these are not perfectly matched. This is called the transactions motive for holding cash, and the approximate size of the cash reserve can be estimated by forecasting cash inflows and outflows and by preparing cash budgets. In addition to the cash reserve held for day-to-day operational needs, cash may be built up to meet significant anticipated cash outflows, for example those arising from investment in a new project or the redemption of debt [9].

Cash Conversion Cycle: the cash conversion cycle is used in measuring cash management, and it represents the interaction between the components of working capital and the flow of cash within a company [14]. Cash conversion cycle can also be used to determine the amount of cash needed for any sales level; it is the period of time between the outlay of cash on raw materials and the inflow of cash from the sale of finished goods, and represents the number of days of operation for which financing is needed.

Days Working Capital: Days' working capital is the days operating cycle less trade creditors (accounts payables period, in days); it measures the liquidity risk of the firms [15]. They further lament that, days working capital is a measure of the cash conversion cycle that gives insight about the underlying health of a business. It is a key metric because it measures the average number of days tied up in net working capital in the operating cycle. If day's working capital is trending upwards over time then it will have a negative financial impact on overall company profit.

\section{Concept of Profitability}

According to Raheman et al. [13] every business is most concerned with its profitability, they defined profitability as the ability to make profit from all the business activities of an organization, company, firm, or an enterprise. Additionally, it shows how efficiently the management can make profit by using all the resources available in the market. One of the most frequently used tools of financial ratio analysis is profitability ratios, which are used to determine the company's bottom line.

\section{Working Capital Management and Firm Profitability}

Existing literature is strongly with the view that efficient working capital improves profitability. In this context, profitability refers to the ability of an enterprise to generate profits from its investments; working capital management affects profitability in several ways [16]. For instance, the management of 
cash, debtors and stocks affects the level of profits made by an enterprise. According to him, the excessive holding of stocks leads to high stock handling costs, deterioration in the value of stocks due to damage and obsolescence, theft or pilferage by employees and wastage. All these are cost to the firm which reduces its profitability.

\section{RESEARCH METHODOLOGY}

This research adopts correlation and ex-post facto designs. This ex-post facto research aims to study the impact of working capital management empirically on the profitability of pharmaceutical companies, while the correlation design is to explore the degree of association between all the variables under consideration. The choice of correlation research design in this study is informed by the fact that, the aim of the design is to investigate the relationships between variables and to estimate the impact of one the variable (independent variable) on another (dependent variable), so as to establish a causal relationship or otherwise among the variables. This is therefore consistent with the objective of the study. Our model is explained as follows:

GOPit $=\alpha 0+\beta 1$ ACRit $+\beta 2$ ACPit $+\beta 3$ INVit + Eit

Where: ACRit $=$ Account Receivable of firm $\mathrm{i}$ in year $\mathrm{t}$

ACPit $=$ Account Payable of firm $i$ in year $t$

INVit $=$ Inventory of firm $\mathrm{i}$ in year $\mathrm{t}$

Eit $=$ error term of firm $\mathrm{i}$ in year $\mathrm{t}$

$\alpha 0=$ is the intercept

$\beta 1-\beta 6=$ coefficient of independent variables

Table-1: Definition of Dependent and Independent Variables

\begin{tabular}{|l|l|}
\hline \multicolumn{1}{|c|}{ Variables } & \multicolumn{1}{c|}{ Measurement } \\
\hline $\begin{array}{l}\text { Dependent variable: } \\
\text { Gross Operating Profit }\end{array}$ & (Sales - cost of goods sold)/(total assets - fixed financial assets) \\
$\begin{array}{l}\text { Independent variables } \\
\text { Accounts Receivables }\end{array}$ & Accounts Receivables $\times 365$ ) $/$ Sales \\
Accounts Payables & (Accounts Payable $\times 365$ ) $/$ Cost of Goods Sold \\
& \\
Inventory & (Inventories $\times 365$ ) $/$ Cost of Goods Sold \\
\hline
\end{tabular}

Adopted from elbadry 2018

\section{Sample and data collection}

In this study we use all the nine pharmaceutical companies listed on the floor of Nigerian Stock Exchange as at 31st December, 2018. Data for the study was collected from secondary data from secondary sources, which is financial statements of all the sampled firms of the study, for the period of five years $(20013$ - 2018). All financial ratios have been calculated using income statements and balanced sheet of the companies.

\section{RESULT AND DISCUSSIONS Descriptive Statistics}

The descriptive statistics of the data collected for the study is presented and discussed in this section. The summary of the descriptive statistics of the data collected is presented in Table 4.1 as follows;

Table-1: Descriptive Statistics of the Variables

\begin{tabular}{|l|cc|l|l|l|l|l|l|}
\hline VARIABLES & Min & Max & Mean & SD & Skewness & Kurtosis & N \\
\hline GOP & 0.25 & 103.33 & 46.74 & 22.66 & 0.5810 & 2.6514 & 50 \\
\hline ACR & 16 & 446 & 132.58 & 83.48 & 1.6682 & 6.4287 & 50 \\
\hline ACP & 5 & 351 & 131.24 & 96.29 & 0.4004 & 1.9330 & 50 \\
\hline INV & 25 & 530 & 174.56 & 101.94 & 1.1142 & 4.3409 & 50 \\
\hline \multicolumn{7}{|c|}{ Source: STATA Output }
\end{tabular}

Table1: shows that our measure of profitability, gross operating profit (GOP) has a minimum value of 0.25 and 103.33 as the maximum value. The average value of the GOP is 46.74 with standard deviation of 22.66, signifying that the data deviate from both sides of the 58 mean values by 22.66. This implies that there is a wide dispersion of the data (profitability of listed pharmaceutical firms in Nigeria) from the mean, because of the large value of standard deviation which is closed to the mean. The kurtosis value of 2.6514 also suggests that majority of the data are higher than mean, as such the data did not meet the Gausian distribution assumption. Similarly, the coefficient of Skewness 0.5810 implies that the data is positively skewed, and thus, the data did not meet the symmetrical distribution assumption. 
The results from the table also indicate that the minimum and maximum values of the account receivables (ACR) are 16 and 446 days respectively, with the mean value of 132.58 days and standard deviation of 83.48. This shows that the sample firms have an average of about 133 account receivables collection period, and the standard deviation value implies that there is dispersion from the mean value by 83.48 days in the sample firms. The coefficient of Skewness 1.6682 implies that the data is positively skewed, and thus, the data does not meet the symmetrical distribution assumption. On the other hand, the kurtosis value of 6.4287 also shows that most of the values are higher than the mean, and thus the data did not meet the Gausian distribution assumption.

The descriptive statistics from Table 4.1 shows that account payables (ACP) period has a minimum and maximum value of 5 and 351 days respectively. On average, the accounts payables period in the sample pharmaceutical firms is 131.24 days with standard deviation of 96.29 days. That is, the deviation from the mean is 96.29 days; the coefficient of Skewness 0.4004 implies that the data is positively skewed, and therefore did not conform to the symmetrical distribution requirement. Moreover, the coefficient of Kurtosis 1.9330 also indicates that the ACP variable did not meet the Gausian distribution assumption.

The table also indicates that on average, the days sales in inventory (INV) is 174.56 days with standard deviation of 101.94, implying that the deviation from the mean is 101.94 days in the 59 sample firms. The minimum and maximum values of days in inventory are 25 and 530 days respectively. The coefficient of skewness 1.1142 indicates that the data is positively skewed, that is, the data did not meet the symmetrical distribution requirement. Similarly, the coefficient of kurtosis of 4.3409 implies that the Gausian distribution is not met.

Table-4.2: Results of Normality Test

\begin{tabular}{|l|l|l|l|l|l|}
\hline Vriables & W & V & Z & PROB $>$ Z & N \\
\hline GOP & 0.9390 & 2.868 & 2.247 & 0.0123 & 50 \\
\hline ACR & 0.8551 & 6.813 & 4.092 & 0.0000 & 50 \\
\hline ACP & 0.9259 & 3.484 & 2.662 & 0.0039 & 50 \\
\hline INV & 0.9139 & 4.046 & 2.981 & 0.0014 & 50 \\
\hline \multicolumn{7}{|c}{ Source: STATA Output }
\end{tabular}

The variables of the study are subjected to Shapiro-Wilk (W) test for data normality; the technique test the null hypothesis (that the data is normal), that is, the variable came from a normally distributed population. Table 4.2 indicates that the data for all the variables are not normally distributed, because the Pvalues are significant at $1 \%$ level of significance (ACR, $\mathrm{ACP}, \mathrm{INV}$, CTS and CTCL, from Prob $>\mathrm{Z}$ value of $0.0000, \quad 0.0039,0.0014,0.0000$, and 0.0000 respectively): and 5\% level of significance (GOP and
CCC, from Prob $>Z$ value of 0.0123 and 0.0184 ). Thus, the null hypothesis (that, the data is normally distributed) is rejected. This may have effects on the results, as most of the parametric tools of analysis including regression assumed that the data is normally distributed.

\section{CONCLUSION}

Based on the key findings of this research, the study concludes that a significant relationship exists between the management of working capital components (account receivables, account payables, inventory, cash conversion cycle, operating cash flows to sales, and cash ratio) and the profitability of listed pharmaceutical firms in Nigeria. Specifically, the study concludes that, account receivables management has a statistical significant negative impact on the profitability of listed pharmaceutical firms in Nigeria. The study also concludes that account payables management has significant positive effects on the profitability of listed pharmaceutical firms in Nigeria. Moreover, the study concludes that the sales days in inventory has a significant negative impact on the profitability of listed pharmaceutical firms in Nigeria.

\section{REFFERENCE}

1. Mohamad, N. E. A. B., \& Saad, N. B. M. (2010). Working capital management: The effect of market valuation and profitability in Malaysia. International Journal of Business and Management, 5(11), 140.

2. Owolabi, S. A., \& Alu, C. N. (2012). Effective working capital management and profitability: A study of selected quoted manufacturing companies in Nigeria. Economics and Finance review, 2(6), 55-67.

3. Singh, K., \& Asress, F. C. (2010). Determining working capital solvency level and its effect on profitability in selected Indian manufacturing firms.

4. Capital, L. (2008). Nigeria's Chemical \& Paints Industry (An Analytical View). Report prepared by Lead Capital Limited, 1-9.

5. Al-Abass, H. S. (2018). Effect of working capital management on profitability of cement sector listed companies. International Journal of Academic Research in Accounting, Finance and Management Sciences, 8(1), 137-142.

6. Dong, H. P., \& Su, J. T. (2010). The relationship between working capital management and profitability: a Vietnam case. International Research Journal of Finance and Economics, 49(1), 59-67.

7. Sharma, A. K., \& Kumar, S. (2011). Effect of working capital management on firm profitability: Empirical evidence from India. Global Business Review, 12(1), 159-173.

8. Van Horne, J. C., \& Wachowicz, J. M. (2004). Fundamentals of financial management. Upper 
saddle River, New York: Prentice Hall International.

9. Van Horne, J. C, \& Wachowicz, J. M. (1995). Fundamentals of Financial Management, Prentice Hall, Englewood Cliffs, NJ.

10. Osisioma, B. C. (1997). Sources and management of working capital. Journal of Sciences, Awka: 2. January.

11. Pass, C.L., \& Pike, R.H. (1984). An Overview of Working Capital Management and Corporate Financing Management finance 10(3): 1-11.

12. Uyar, A. (2009). The Relationship of cash conversion cycle with firm size and profitability:An empirical investigation in Turkey. International Research Journal of Finance and Economics, 24: 186-193.

13. Raheman, A., \& Nasr, M. (2007), Working Capital management and profitability, case of Pakistani firms, International Review of Business Research papers, 3(1), 279-300.

14. Wang, Y. J. (2002). Liquidity management, operating performance and corporate value: Evidence from Japan and Taiwan. Journal of Multinational Financial Mangement., 12(2), 159169.

15. Vineet, K., \& Sukhdev, S. (2013). Managing Efficiency and Profitability Through Working Capital: An Empirical Analysis of BSE 200 Companies Asian Journal of Business Management 5(2): 197-207, 2013

16. Deloof, M. (2003). Does working capital management affect profitability of Belgian firms?. Journal of business finance \& Accounting, 30(3- 4), 573-588. 